\title{
Soft Skill Education in the Positive Mindset Frame for the Department of Mechanical Engineering Education Graduates
}

\author{
Th. Sukardi, Subiyono \\ Faculty of Engineering, Universitas Negeri Yogyakarta \\ Yogyakarta, Indonesia \\ E-mail: thomkar234@yahoo.co.id
}

\begin{abstract}
The aim of this study are to know the description of soft skill quality and mindset quality of college students majoring mechanical engineering education department in engineering faculty of Yogyakarta State University in which the finding is used as a basic guideline, approach, and strategy in the teaching process as a means to apply soft skill and positive mindset towards the graduates. This study uses population-based research by involving 191 students as research subjects from the undergraduate and vocational program in the second semester, fourth semester, and the sixth semester focusing on: option drawing, fitting, and fabrication. In collecting the data the writers distribute questionnaires, while in analysing the data the writers use grade point average analysis towards each of soft skill quality and mindset performance. This study leads to the finding that grade point average for soft skill quality performance is $\mathbf{1 . 9 5}$ and grade point average for mindset quality performance is $\mathbf{2 . 8}$. Therefore, to sum up, the description of students' soft skill quality is still below average and the description of mindset quality is categorized moderate.
\end{abstract}

Keywords--soft skill, frame, positive mindset, mindset quality performance

\section{INTRODUCTION}

Soft skill is commonly defined as a personal quality required to apply for a job, to do a job as well as to run a business. In other words, soft skill is a skill or an ability to manage his/herself and others supposed to be owned by the graduates of mechanical engineering education. This soft skill must be developed together with a hard skill which will be used as the weapon and the spirit in the journey based on the positive mindset to reach visible achievement for short term period, medium period, as well as long-term period. The study conducted by Havard University and in some other famous universities shows that $85 \%$ of someone's success is derived from soft skill, while $15 \%$ of other aspects are caused by skill [1].

Widarto [2] suggests that soft skill aspect based on Clop Work model consists of creativity, initiative, honesty, ethics, work ethos, adaptation, tolerance, responsibility, independence, cooperation, communication, confidence, leadership, discipline and politeness. This thing is in line with the result of the survey conducted by [2] showing that some necessary characteristics in work are responsibility, honesty, creativity, discipline, work ethos, cooperation, confidence, tolerance, leadership, adaptation, independence, ethics, politeness, and communication [3]

Mindset, as stated by [4], is defined as belief, conviction, behaviour, way of thinking, opinion and one's attitude determining the level of success and one's future, while conviction is something that is believed to be true or a mind acceptance that something is true. In this sense mindset influences behaviour, behaviour influences action, action shapes habit, habit forms characteristic, and characteristic determines success. Moreover, level of success will influence mindset and the like. Then the question is, what would happen if soft skill which has been prepared well does not run like what it is expected that is soft skill in the frame of positive mindset

Roberts Dillts gives definition to belief as a generalisation from experience. Michael Hall adds that belief is a conviction that has been confirmed deliberately or not deliberately. Further, the term mental block or limiting belief is defined as a wrong belief that can inhibit or stop the purpose [5]. Similarly, Robert Dilts mentions that there are three things that make a belief. They are a belief relating to the cause of a relation, a belief relating to meaning-making of a relation, and a belief relating to the generalisation of a limitation. There are some factors which influence mindset as stated by [6]. He explains that most mindset is descended from family members, society, religious leader, and teachers. Besides, some cases show the occurrence of imitating or making positive change. However, unfortunately, the change sometimes does not last long because people try to change the result without changing his/her mindset. Having the same idea, Syutra [7] says that there are three factors that influence mindset: (1) information input (2) environment (3) experience in the past. Another opinion sees mindset as likely a belief or doctrine stored in brain influenced by environment. About mental framing, Yusdarmanto [8] states that shaping of mental framing is caused by environment, experience in the past, knowledge, former results, and mental shadow in doing massive action.

As the matter of the fact, then, the very first step in determining suitable guidance is by developing human resources involving mental, point of view, and way of thinking. It is because the readiness quality is an encouragement for other factors. As human resources improve, he/she tends to be aware, motivated, and enthusiastic to be better. 
From elaboration above, therefore, the problem is about how to make the graduates from mechanical engineering education from Faculty of Engineering Yogyakarta State University have soft skill quality in the frame of a positive mindset. In order to make it come true, the first step is knowing the real representation of the previous quality. The aim of this study is to get the illustration of soft skill quality as well as mindset quality owned by the college students at the recent time. The advantage of this study is as an evaluation, moreover, it can be also used to get direction, focus, therapy, doctrine, shaping, and developing soft skill and mindset that both need to owned by the graduates of mechanical engineering education of Engineering Faculty Yogyakarta State University.

\section{METHOD}

This study took place in the Department of Mechanical Engineering Education Department, Faculty of Engineering Yogyakarta State University belongs to survey-based research as well as a study involving population. The population consisted of 191 college students majoring Mechanical Engineering Education participated by students from an undergraduate program and vocational study program. The students were in the even semester: semester 2 , semester 4 , and semester 6 . There were two variables analyzed that consisted of (1) soft skill and (2) mindset. In collecting the data, the questionnaires were distributed in which the contents are about giving response "True" or False". Besides, the writers also give students questionnaires in the form of open questions. This type of questionnaires free the students to answer the questions based on their own perception. Furthermore, other some steps taken were collecting the data, analysing the data seen from students' grade point average performance, giving a recommendation, and making a report.
To analyze the two variables, the writers put some indicators for each variable. The first variable namely soft skill includes creativity, relation within society, discipline, carefulness, cooperation, commitment, dignity, problemsolving, confidence, mental emotion, responsibility, innovation, communication skills, diligence, objectivity, feedback and flexibility. In calculating the analysis, the writers use the following formula:

( the number of students choosing "true" in soft skill aspect / the number of students ) X $100 \%$

Moreover, the second variable namely mindset consists of worries about future perception toward fate, Luck perception, perception about knowledge and skill derived from studying in the faculty of engineering, competition bravery, belief about success, role model, positive thinking, fighting to apply for a job, and prayer. Similarly, the scoring for this variable is as follows:

(the number of students choosing "true" in mindset aspect / the number of students) X100\%

\section{FINDING AND DISCUSSION}

Table 1,2 and 3 show both the data soft skill and mindset based on some criteria such as: the data taken from students of bachelor degree and vocational study, the semester, and options that can be seen in the below tables and diagram.

TABLE 1. RESPONDENTS DISTRIBUTION PER STUDY PROGRAM, SEMESTER AND OPTION

\begin{tabular}{l|ll|l|ll|l}
\multicolumn{3}{c}{$\begin{array}{c}\text { Bachelor Degree Progran } \\
\text { (140 students) }\end{array}$} & \multicolumn{3}{c}{$\begin{array}{c}\text { Vocational Study } \\
\text { Program (51 Students) }\end{array}$} \\
\hline Semester 2 & \multicolumn{3}{c}{ Semester 4 Semester 2 } & Semester 4 \\
\cline { 2 - 6 } & Fitting & Drawing & fabrication & (drawing) & & \\
36 & 10 & 13 & 20 & 31 & 22 & 29 \\
\hline
\end{tabular}


TABLE 2. SOFT SKILL'S VALUE DESCRIPTION

\begin{tabular}{|c|c|c|c|c|c|c|c|c|c|c|}
\hline \multirow[t]{2}{*}{ No } & \multirow[t]{2}{*}{ Soft Skill Aspects } & \multirow{2}{*}{$\begin{array}{l}\text { Bachelor Degree } \\
\text { and Vocational } \\
\text { Study Program (all } \\
\text { semester) }\end{array}$} & \multicolumn{8}{|c|}{$\begin{array}{l}\text { Study Program/Semester/Option } \\
\text { (total students) }\end{array}$} \\
\hline & & & $\begin{array}{l}\text { Bachelor } \\
\text { Degree } \\
(140)\end{array}$ & $\begin{array}{l}\text { Vocational } \\
\text { Study } \\
(51)\end{array}$ & $\begin{array}{l}\text { Semester } \\
2 \\
(58)\end{array}$ & \begin{tabular}{|l} 
Semester \\
4 \\
$(102)$
\end{tabular} & $\begin{array}{l}\text { Semester } \\
6 \\
(31)\end{array}$ & $\begin{array}{l}\text { Fitting } \\
(40)\end{array}$ & $\begin{array}{l}\text { Fabrication } \\
(20)\end{array}$ & $\begin{array}{l}\text { Drawing } \\
\text { (44) }\end{array}$ \\
\hline 1 & Creativity & 76.43 & 80.78 & 72.05 & 61.95 & 89.90 & 64.50 & 80.00 & 90 & 82.25 \\
\hline 2 & Relationship among people & 60.73 & 67.51 & 33.95 & 57.95 & 58.07 & 61.29 & 77.50 & 70 & 57.54 \\
\hline 3 & Discipline & 80.11 & 83.03 & 75.40 & 77.05 & 84.42 & 74.10 & 80.00 & 75 & 87.05 \\
\hline 4 & Carefulness & 54.45 & 52.16 & 51.35 & 52.25 & 56.80 & 48.31 & 67.50 & 50 & 54.90 \\
\hline 5 & Detail & 60.73 & 64.12 & 53.55 & 51.85 & 64.15 & 67.70 & 65.00 & 45 & 76.15 \\
\hline 6 & Coorporation & 73.29 & 69.90 & 79.95 & 71.90 & 73.75 & 70.90 & 75.00 & 45 & 81.60 \\
\hline 7 & Commitment & 87.95 & 84.14 & 59.60 & 75.20 & 92.15 & 70.90 & 75.00 & 90 & 77.75 \\
\hline 8 & Dignity & 57.59 & 63.56 & 47.50 & 45.65 & 60.85 & 58.00 & 62.50 & 50 & 75.15 \\
\hline 9 & Problem Solving & 43.97 & 45.50 & 52.10 & 25.60 & 57.87 & 41.90 & 42.50 & 55 & 51.7 \\
\hline 10 & Convidence & 50.78 & 57.10 & 40.00 & 40.60 & 57.37 & 54.80 & 62.50 & 65 & 54.3 \\
\hline 11 & Mental & 50.78 & 37.73 & 49.04 & 46.85 & 80.19 & 32.25 & 42.50 & 45 & 35.32 \\
\hline 12 & Emotion & 32.00 & 53.03 & 45,68 & 48.60 & 51.66 & 61.29 & 57.50 & 55 & 52.70 \\
\hline 13 & Responsibility & 64.29 & 65.76 & 48.04 & 38.50 & 66.81 & 51.60 & 67.50 & 60 & 82.60 \\
\hline 14 & Innovation & 88.48 & 84.90 & 83.31 & 66.94 & 92.40 & 80.60 & 90.00 & 90 & 91.90 \\
\hline 15 & Communicating Skill & 40.3 & 41.95 & 37.10 & 36.20 & 41.60 & 83.80 & 42.50 & 40 & 45.63 \\
\hline 16 & Diligence & 64.92 & 71.18 & 55.36 & 53.05 & 77.20 & 45.16 & 87.50 & 85 & 70.85 \\
\hline 17 & Objectivity & 62.82 & 63.82 & 50.25 & 43.50 & 63 & 51.60 & 70.00 & 50 & 78.75 \\
\hline 18 & Using Feedback & 47.64 & 52.73 & 41.65 & 43.50 & 53.7 & 80.60 & 55.00 & 45 & 61.03 \\
\hline 19 & Fexibility & 42.40 & 45.14 & 35.80 & 38.50 & 43.07 & 45.16 & 52.50 & 25 & 51.05 \\
\hline 20 & Spirit & 65.96 & 63.50 & 54.30 & 52.75 & 64.65 & 48.31 & 77.50 & 50 & 76.79 \\
\hline
\end{tabular}

Note: Score : (the number of students answering "true" on soft skill aspect/ total students) X 100\%

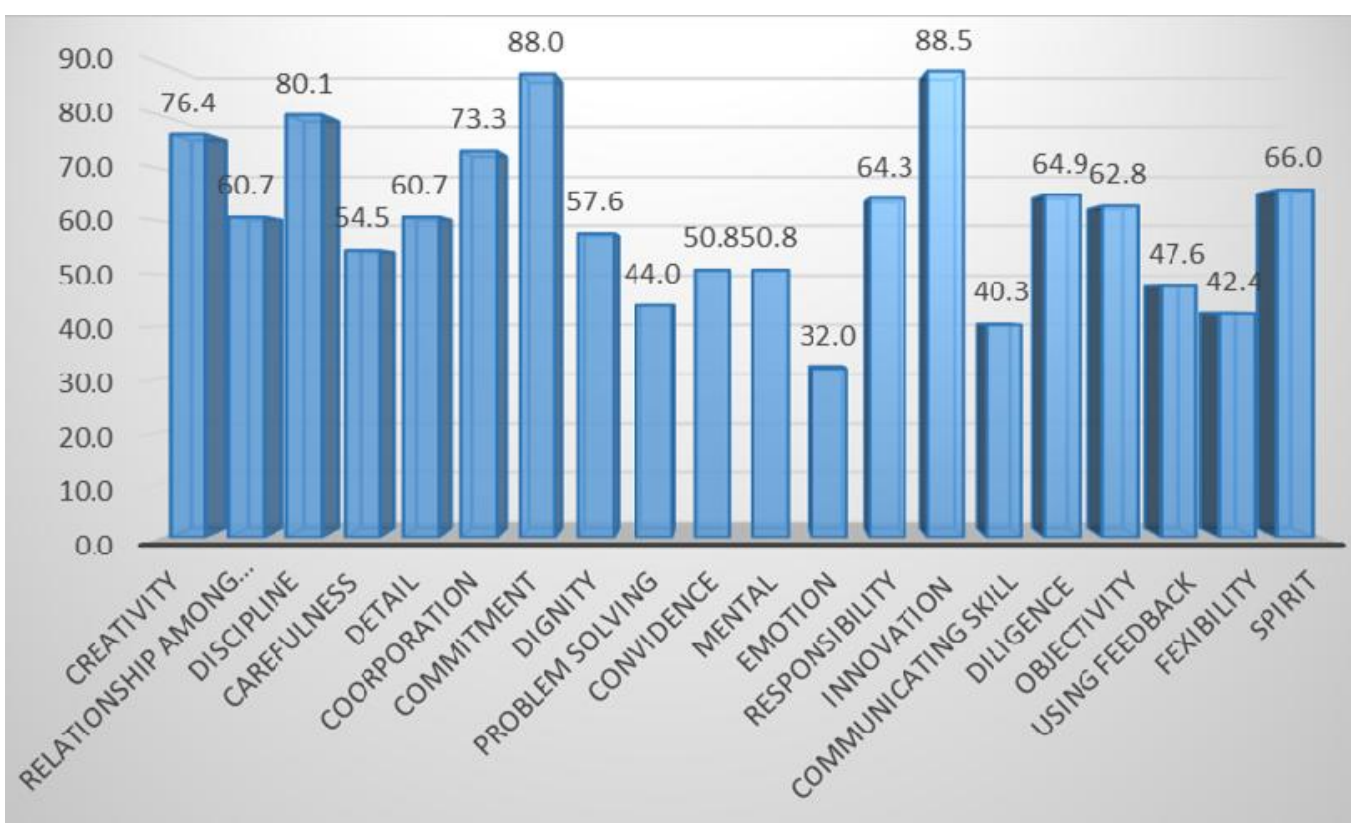

Fig. 1. Soft Skill ‘s Value Description of The Students of Mechanical Engineering Education Department 
TABLE 3. MINDSET'S VALUE DESCRIPTION

\begin{tabular}{|c|c|c|c|c|c|c|c|c|c|c|}
\hline \multirow[t]{2}{*}{ No } & \multirow[t]{2}{*}{ Mindset Aspects } & \multirow{2}{*}{\begin{tabular}{l|} 
Bachelor \\
Degree and \\
Vocational \\
Study Program \\
(all semester)
\end{tabular}} & \multicolumn{8}{|c|}{$\begin{array}{c}\text { Study Program/Semester/Option } \\
\text { (total students) }\end{array}$} \\
\hline & & & $\begin{array}{l}\text { Bachelor } \\
\text { Degree } \\
(140)\end{array}$ & $\begin{array}{l}\text { Vocation } \\
\text { al Study } \\
(51)\end{array}$ & $\begin{array}{l}\text { Semester } \\
2 \\
(58)\end{array}$ & $\begin{array}{l}\text { Semester } \\
4 \\
(102)\end{array}$ & $\begin{array}{l}\text { Semester } \\
6 \\
(31)\end{array}$ & $\begin{array}{l}\text { Fitting } \\
(40)\end{array}$ & $\begin{array}{l}\text { Fabrication } \\
\text { (20) }\end{array}$ & $\begin{array}{l}\text { Drawing } \\
\text { (44) }\end{array}$ \\
\hline 1 & Worried about future & 61.00 & 72.66 & 42.26 & 42.65 & 72.87 & 70.90 & 82.50 & 90 & 77.75 \\
\hline 2 & Fate Perception & 50.26 & 49.70 & 54.35 & 29.25 & 60.97 & 54.80 & 60.00 & 50 & 58.15 \\
\hline 3 & Perception towards luck and miracle & 27.77 & 31.34 & 22.80 & 20.10 & 33.97 & 25.80 & 30.00 & 40 & 32.10 \\
\hline 4 & $\begin{array}{l}\text { Perception towards knowledge and } \\
\text { skill derived from Mechanical } \\
\text { Engineering Department of } \\
\text { Yogyakarta State University }\end{array}$ & 72.25 & 67.90 & 74.25 & 66.90 & 69.22 & 77.40 & 85.00 & 70 & 61.75 \\
\hline 5 & $\begin{array}{l}\text { Perception towards competing } \\
\text { encouragement with graduates from } \\
\text { other famous universities }\end{array}$ & 87.43 & 94.60 & 86.85 & 83.05 & 96.00 & 96.70 & 97.50 & 90 & 98.95 \\
\hline 6 & Belief in being successful person & 96.33 & 97.76 & 93.00 & 87.50 & 100.00 & 100 & 100.00 & 100 & 100.00 \\
\hline 7 & Role model & 93.19 & 97.72 & 83.85 & 78.65 & 99.12 & 100 & 100.00 & 100 & 100.00 \\
\hline 8 & $\begin{array}{l}\text { Positive thinking, positive feeling, and } \\
\text { prejudice }\end{array}$ & 37.69 & 49.32 & 34.20 & 35.70 & 50.86 & 38.70 & 47.50 & 90 & 38.58 \\
\hline 9 & Fighting to apply for a job & 58.63 & 66.90 & 42.38 & 31.85 & 70.46 & 74.19 & 67.50 & 60 & 83.24 \\
\hline 10 & SMART prayer & 96.33 & 76.16 & 50.35 & 45.05 & 80.92 & 67.70 & 82.50 & 80 & 80.00 \\
\hline
\end{tabular}

Note: Score: (the number of students answering "true" on mindset aspect/ total number of the students X 100\%)

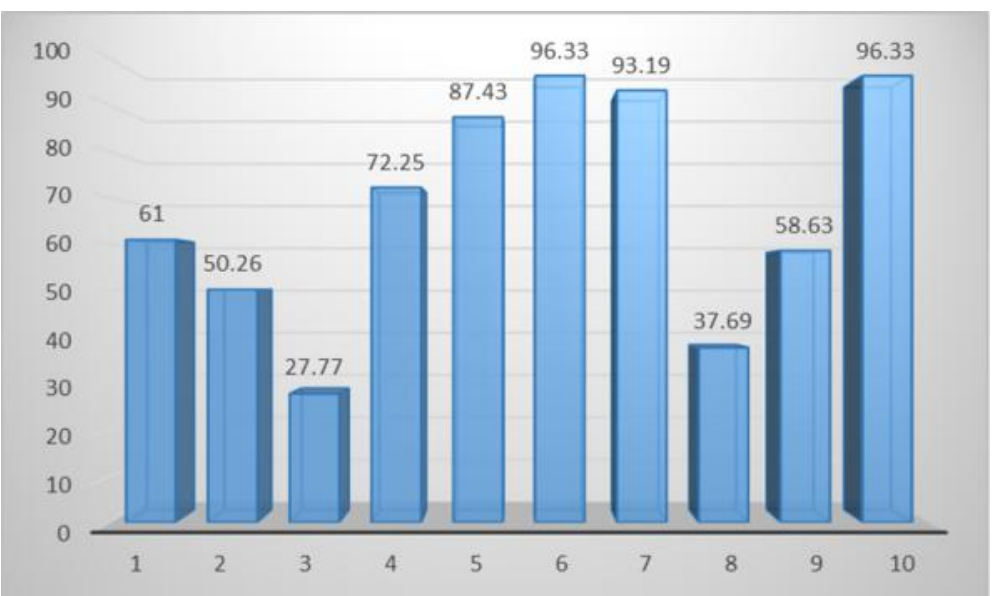

Fig. 2. Mindset' Value Description of The Students of Mechanical Engineering Education Department

Note :

\begin{tabular}{|l|l|l|}
\hline Number & \multicolumn{1}{|c|}{ Mindset Aspects } & \multicolumn{1}{|c|}{ Score } \\
\hline 1 & Worries about the future & 61 \\
\hline 2 & Fate perception & 50.26 \\
\hline 3 & Luck perception/miracle & 27.77 \\
\hline 4 & Knowledge and skill derived from UNY & 72.25 \\
\hline 5 & Belief in competition skill with graduates from famous universities & 87.43 \\
\hline 6 & Belief in success & 96.33 \\
\hline 7 & Idols & 93.19 \\
\hline 8 & Positive thinking and positive feeling & 37.69 \\
\hline 9 & Fighting in getting a job & 58.63 \\
\hline 10 & SMART prayer & 96.33 \\
\hline
\end{tabular}


Table 1,2 and 3 can be interpreted that the two aspects from mindset : (1) competing for encouragement and (2) worries about the future lead to some issues. First of all, the reasons of why the graduates of the mechanical engineering department of Yogyakarta State University are encouraged to compete with other graduates from famous universities are due to their confidence. It is because during studying in UNY, they have got sufficient facilities as well as frequent opportunity to practice. Besides, UNY is also one of the big universities in Indonesia. In this sense, the big name of UNY does not solely become the reason of the graduates' success, but it mostly depends on each person's effort. Moreover, Faculty of Engineering of UNY often wins the competition either in national level or in international level. Additionally, UNY has accreditation value "A". UNY also has many successful alumni who serve good position in factories.
The next reason is about future worries. In this case, the causes of worries relate to some factors such as: (1) a job vacancy for civil servant is limited (2) the government cannot provide enough jobs (2) the graduates are not confident (3) high competition (3) they do not know what they will be (4) they do not know where to work (5) they have less knowledge (6) they have few experience running an organisation (7) they are not sure (8) they think that they are indisciplined (9) worries about unexpected future (10) they do not know what will happen in the future (11) they are worried that they cannot make their parents' dreams come true (12) failure (13) they think that future is a mystery (14) there are some challenges they cannot handle (15) they do not have much money (16) they do not have vision where to go (17) they do not have enough knowledge (18) they have wasted their teenhood (18) they do not have specific expertise (19) worried about failure (20) parents condition (21)they are not serious.

TABLE 4. ROLE MODEL

\begin{tabular}{|c|c|c|c|}
\hline No & Role Models & Number of siudents & Number of studeuts $(\%)$ \\
\hline 1 & Tcachcr- & 3 & 1.5 \\
\hline 2 & Lecturer & 1 & 0.5 \\
\hline 3 & A.lumnus & 0 & 0 \\
\hline 4 & Friends/Close fiends & 3 & 1.5 \\
\hline 5 & Artist & 1 & 0.5 \\
\hline 6 & Prophet & 73 & 38 \\
\hline 7 & Religion figures & 9 & 4.7 \\
\hline 8 & Parents & 43 & 22.5 \\
\hline 9 & Racer & 2 & 1 \\
\hline 10 & Successful people (trom Indonesia) & 17 & 21.26 \\
\hline 11 & Successful people (from other countries) & 2 & 1 \\
\hline 12 & Politician & 4 & 2 \\
\hline 13 & Having no idols & 8 & 4.18 \\
\hline 14 & Motivator & 3 & 1.5 \\
\hline 15 & President/ Ex Presidents of Indonesian Republic & 40 & 20.9 \\
\hline 16 & Enterpreneur & 12 & 6.28 \\
\hline 17 & Heives & 1 & 0.5 \\
\hline 18 & Sportsmen & 9 & 4.7 \\
\hline
\end{tabular}

Note: The number of students $=$ the number of students having related idols/ the number of respondents from bachelor degree and vocational study program. 
TABLE 5. DESCRIPTION OF THE SOURCE OF MOTIVATION

\begin{tabular}{|c|l|c|c|}
\hline No & \multicolumn{1}{|c|}{$\begin{array}{c}\text { The Source of } \\
\text { Motivation }\end{array}$} & $\begin{array}{c}\text { The Number of } \\
\text { Students }\end{array}$ & $\begin{array}{c}\text { The Number of } \\
\text { Students (\%) }\end{array}$ \\
\hline 1 & Parents/family & 152 & 79.58 \\
\hline 2 & Friends & 13 & 6.8 \\
\hline 3 & Future & 6 & 3.14 \\
\hline 4 & Succesful Alumnus & 5 & 2.6 \\
\hline 5 & Teacher & 2 & 1.04 \\
\hline 6 & Lecturer & 6 & 3.14 \\
\hline 7 & Dreams & 3 & 1.57 \\
\hline 8 & Self & 4 & 2.09 \\
\hline 9 & Boy/girlfriend & 5 & 2.6 \\
\hline 10 & Hoby & 1 & 0.5 \\
\hline 11 & Life's stories & 1 & 0.5 \\
\hline 12 & Environment & 1 & 0.5 \\
\hline 13 & Technology & 1 & 0.5 \\
\hline 14 & Successful people & 4 & 2.09 \\
\hline 15 & Condition & 1 & 0.5 \\
\hline 16 & Competition & 1 & 0.5 \\
\hline 17 & The past & 1 & 0.5 \\
\hline 18 & Nothing & 3 & 1.57 \\
\hline 19 & Religion & 1 & 0.5 \\
\hline
\end{tabular}

Note: The number of motivated students: the number of students having particular motivation / respondents from bachelor degree and vocational study program.

Table 5 shows that parents, family, and friends have essential role in motivating the students while only a few students who choose teacher and lecturers as their motivators.

\begin{tabular}{|c|c|c|c|c|}
\hline \multirow[t]{2}{*}{ No } & \multirow[t]{2}{*}{ Aspects } & \multicolumn{3}{|c|}{$\begin{array}{l}\text { The number of indicators getting value } A, B, C / D, \text { Grade Point, and the average of all } \\
\text { aspects }\end{array}$} \\
\hline & & $\begin{array}{l}\text { Bachelor degree } \\
\text { (140 students) }\end{array}$ & \begin{tabular}{|l} 
Vocational Study \\
(51 studeuls)
\end{tabular} & $\begin{array}{l}\text { Bachelor degree and Vocational Study } \\
\text { (191 studenls) }\end{array}$ \\
\hline 1 & Soft Skill & $\begin{array}{l}\text { A-4 } B-3(:-6 \mid)-7 \\
(\mathrm{ip}-2.2 \\
\text { Average }-62.36\end{array}$ & $\begin{array}{l}A-2 B-2 C-1 \\
1)-15(\mathrm{i} P-1,55 \\
\text { Average }-51.39\end{array}$ & $\begin{array}{l}A-2 B-3(-7 D)-8 \\
(i p-1,95 \\
\text { Average }-60.28\end{array}$ \\
\hline 2 & Mindset & $\begin{array}{l}A=1 B=3 C=0 D=3 \\
(\mathrm{ip}-2.8 \\
\text { Average }-70.36\end{array}$ & $\begin{array}{l}A=5 B=1 C=2 \\
1)-2(\mathrm{ip}-2.9 \\
\text { Average }-73.05\end{array}$ & $\begin{array}{l}\mathrm{A}=1 \mathrm{~B}=1 \mathrm{C}=2 \mathrm{D}=5 \\
\mathrm{GH}-2.8 \\
\text { Average }-68.08\end{array}$ \\
\hline
\end{tabular}

Seen from Table 6, based on grade point average performance, the description of soft skill performed by the students shows that students of bachelor degree have a higher value than those of students from the vocational study. Besides, the mindset description is performed better by the students of vocational study than students from bachelor degree.

TABLE 7. SUMMARY OF SOFT SKILL AND MINDSET DESCRIPTION BASED ON SEMESTER

\begin{tabular}{|c|c|c|c|c|}
\hline \multirow[t]{2}{*}{ No } & \multirow[t]{2}{*}{ Aspects } & \multicolumn{3}{|c|}{$\begin{array}{l}\text { The number of indicators getting value } \mathrm{A}, \mathrm{B}, \mathrm{C} / \mathrm{D}, \mathrm{Grade} \text { Point, and the average of all } \\
\text { aspects }\end{array}$} \\
\hline & & $\begin{array}{l}\text { Bachelor degree } \\
\text { (58 students) }\end{array}$ & $\begin{array}{l}\text { Vocational Study } \\
\text { (102 studeuls) }\end{array}$ & $\begin{array}{l}\text { Bachelor degree and Vocational sturiy } \\
\text { (3I sludeuts) }\end{array}$ \\
\hline 1 & Soft Skill & $\begin{array}{l}A-0 B-1 C-2 D-11 \\
\left(\mathrm{Cl}^{2}-1.5\right. \\
\text { Average }-51.41\end{array}$ & $\begin{array}{l}A-5 B-3 C-7 \\
1)-5(i)^{3}-2.4 \\
\text { Average }-66.48\end{array}$ & $\begin{array}{l}A-3 B-1 C-1 D-9 \\
\text { (Al' }-2.115 \\
\text { Average }-59.63\end{array}$ \\
\hline 2 & Mindset & $\begin{array}{l}A-2 B-2 C-0 D-6 \\
G P-2.0 \\
\text { Averagc }=5(1.07\end{array}$ & $\begin{array}{l}A-4 B-3 C-1 \\
D-2 G P-2.9 \\
\text { Average }=73,42\end{array}$ & $\begin{array}{l}A-3 B-4 C-0 D-3 \\
G P-2.7 \\
\text { Average }=70.61\end{array}$ \\
\hline
\end{tabular}


From table 7, it can be analysed that based on grade point average performance, the description of soft skill and mindset performed by students sitting in the semester 4 is higher than students sitting in semester 2 and semester 6 . Added to this, the description of soft skill and mindset performed by students sitting in semester 6 is higher than students sitting in semester 2 .

Furthermore, the following Table 9 and 10 below elaborates the summary of the description of performance quality of the three aspects: purpose, soft skill and mindset.

TABLE 8. CLASSIFICATION OF SOFT SKILL QUALITY PERFORMANCE

\begin{tabular}{|c|c|c|c|}
\hline \multicolumn{4}{|c|}{ Classiflcation } \\
\hline Very Good & Good & Fair & Poor \\
\hline $\begin{array}{l}\text { - Discipline } \\
\text { - Comuniluncil } \\
\text { - Innovation }\end{array}$ & $\begin{array}{l}\text { - Creativity } \\
\text { - Coorporation } \\
\text { - Confidence }\end{array}$ & $\begin{array}{l}\text { - Relationship } \\
\text { among people } \\
\text { - Detail } \\
\text { - I Jigniily } \\
\text { - Responsibility } \\
\text { - Diligence } \\
\text { - Objectivily } \\
\text { - Spirit }\end{array}$ & $\begin{array}{l}\text { - Carefulness } \\
\text { - Problem solving } \\
\text { - Confidence } \\
\text { - Mental } \\
\text { - } \text { Hunotiun } \\
\text { - Communicating } \\
\text { - Ikill } \\
\text { - Ising feedlack } \\
\text { - Tlexibility }\end{array}$ \\
\hline
\end{tabular}

TABLE 9. CLASSIFICATION OF MINDSET QUALITY PERFORMANCE

\begin{tabular}{|c|c|c|c|}
\hline \multicolumn{4}{|c|}{ Classifïcation } \\
\hline Very Grood & Good & Fair & Poor \\
\hline $\begin{array}{l}\text { Competing } \\
\text { encouragement with } \\
\text { graduates from other } \\
\text { famous universities } \\
\text { Belief in becoming } \\
\text { succussful purson } \\
\text { - Idols } \\
\text { - SMAlR prayer }\end{array}$ & $\begin{array}{l}\text { Knowledge, skill, } \\
\text { and experience } \\
\text { gotten from } \\
\text { faculty of } \\
\text { engineering in } \\
\text { tNY }\end{array}$ & $\begin{array}{l}\text { - Worried about } \\
\text { future } \\
\text { - Difficulties in } \\
\text { looking for a job }\end{array}$ & $\begin{array}{l}\text { - Fate perception } \\
\text { Luck perception } \\
\text { Positive thinking, } \\
\text { focling, and } \\
\text { prejudice }\end{array}$ \\
\hline
\end{tabular}

From Table 8, it can be seen that soft skill aspects showing a very good performance are disciplines, commitment, and innovation. The aspects categorized good are creativity, cooperation, confidence. The aspects belonging to the fair are a relationship among people, detail, dignity, responsibility, diligence, objectivity and spirit. Then, the aspects in which performances are considered poor are carefulness, problemsolving, confidence, mental, emotion, communicating skills, using feedback and flexibility.

The next finding shows that soft skill description performed by bachelor degree students is better than those performed by students from the vocational study. Students' soft skill sitting in the fourth semester is better than soft skill performed by students sitting either in semester 2 or semester 6 . From the result, in fact, students studying in bachelor degree program have longer study period than students studying in the vocational study program, hence soft skill development becomes better. Furthermore, seen from the level of the semester, it can be seen that students sitting in semester 4 have better soft skill quality than students sitting in semester 2 . However, soft skill quality performed by students sitting in semester 6 has lower soft skill quality than soft skill performed by students sitting in semester 2 . And it becomes the question.

The study also shows that seen from grade point average performance, the total students' soft skill grade point average studying in bachelor degree and vocational study is only 1,95. It is derived from students' from bachelor degree whose value is 2,2 and grade point average performed by students of vocational study is 1.55 . From this result, it is necessary to improve the quality of students' soft skill because it must be noticed that in Indonesia college students at least should have a grade point average 3.00 or above. It proves that students' emotional intelligence and the role of the right brain do not work as what they supposed to do. 
Table 9 shows that description for mindset aspects quality showing the very good category is students' perception towards competition with graduates from famous universities, belief in becoming successful person, mindset improvement inspired by idols, and prayer. The next aspect belonging to good is perception towards skill and knowledge acquired from the faculty of engineering, Universitas Negeri Yogyakarta. The aspects considered fair are worried about future and difficulties in looking for a job, while the aspects classified as poor are fate perception, luck perception, positive thinking, feeling, and prejudice. Besides, seen from grade point, mindset value performed by students studying in bachelor degree and vocational study is relatively equal in which each value shows result 2.9 and 2.8. Therefore, from the result, it is still necessary to make more efforts in order to improve students' mindset quality so that they can have minimum grade point average 3.00. Seen from semester level, students' mindset sitting in semester 4 has better value (2.9) than students sitting in semester 6 whose value is (2.7) as well as students sitting in semester 2 whose value is (2.0). As a result, the higher the semester level the better the quality mindset performed by the students. If the students' mindset quality is below average, it could be caused by some factors like fate perception, luck perception, positive thinking and feeling. This thing is common because a good mindset is owned by those who are creative and have good value in emotional intelligence. In this sense, hence, during teaching and learning process, teachers need to pay more attention to emotional intelligence.

A finding that UNY must be proud of is that students give high value in the three mindset aspects, they relate to students' belief in knowledge, skill, and experience that they have got during studying in the faculty of engineering in UNY. The other aspects are that students are encouraged to compete with graduates from other famous universities as well as students' belief to be successful people.

The result of this study shows that $96,93 \%$ of the students have idols and the idols come from some professions. It can be seen from the following percentage: $38 \%$ students inspired by the prophets, $22.5 \%$ students love their family, $24.60 \%$ for successful people from other countries, $20.9 \%$ for President/Ex-Presidents of Indonesian Republic, $4.7 \%$ for religious figures, $4.7 \%$ for sportsmen, $6.28 \%$ for entrepreneurs, $1.5 \%$ for teachers, and $0.5 \%$ for lecturer. The prophet positions number one, successful people from other countries are in number 2, and parents have a position in number 3 . Those orders are common, but it is unfortunate that teacher and lecturer have the lowest ranking that each percentage is $1.5 \%$ and $0.5 \%$

In addition to idols, the next value is seen from the source of motivation. The following order shows that parent is in the first place, that $79.58 \%$ of students choose parents as their motivator. Further, it is followed by parents $6.28 \%$, friends $6.8 \%$, future $3.14 \%$, and alumnus $2.6 \%$, and having no motivator $1.57 \%$. In this case, parents become the most motivating ones because parents are the ones who take care of them, pay their tuition, give advice, and support them every time. Motivation gives many advantages in improving several things such as encouragement, spirit, productivity, discipline, creativity, responsibility, and challenge. In order make dreams come true, people use their knowledge, skill, experience and fighting spirit. Besides, support, inspiration and idols also can be factors of success. However, all of them cannot always be relied on if the mindset does not change. They want the same result with a different mindset.

Furthermore, based on the theory of Purwato Sudarmanto (2010: 36-41) about the mental frame, it can be said that the idol and the source of motivation is a mental frame of the formation of a positive mindset. In addition, future concerns are also influenced by negative mindset.

\section{CONCLUSION}

In mindset aspects, 191 students studying in bachelor degree and in a vocational study on average have a very good value seen from some aspects such as students' perception towards competition among graduates from famous universities, belief in becoming a successful person, mindset improvement caused by idols, and smart prayer. Another result also shows that aspects belonging to 'good' is perception towards skill and knowledge had by the students during studying in the faculty of engineering UNY. There are two aspects categorized 'fair', they are worried about the future and difficulties in getting jobs. In soft skill aspects, 191 students sitting in semester 2 to semester 6 overall have description quality performance categorized 'very good'. Those aspects are discipline, commitment, and innovation. Other aspects such as creativity, cooperation, confidence, responsibility, diligence, objectivity, and spirit belong to 'good'. Additionally, aspects categorized 'poor' are carefulness, problem-solving, confidence, mental, emotion, communicating skills, using feedback, and flexibility. Soft skill aspects that have fulfilled the qualification are creativity, discipline, corporation, and innovation.

From above conclusion, thus it is suggested that the lecturers have more effort to become a role model as well as an idol for the students. The role of lecturer functioning as a motivator needs to be improved. Besides, lecturers must encourage the students to have more idols based on admired characters.

\section{REFERENCES}

[1] Eloy Zaluku. Life Succes Triangke. Jakarta : Kompas Gramedia . pages 4-5.2012.

[2] Widarto. Pengembangan Soft Skill Mahasiswa Pendidikan Vokasi Melalui Clop Work. Yogyakarta: Paramitra Publishing. 2011.

[3] Sudji Munadi. Pengembangan Karakter Kerja Melalui Pembelajaran Praktik Proses Permesinan. Memantapkan Pendidikan Karakteruntuk Melahirkan Insan Bermoral Humanis dan Profesional. Maman Suryaman. Yogyakarta: UNY Press. 2014.

[4] Adi W.Gunawan. Hypnotherapy for Children. Jakarta : Gramedia Pres. 2010.

[5] Antonius Arief. Mental Blok. Titik Media Publisher. 2012.

[6] James Arthur Ray. The Science of Success. Jakarta : Gramedia Pustaka Utama. 2007.

[7] Abdullah Khafi Syutra. Misteri Alam Bawah Sadar Manusia Yogyakarta : DIVA Pres. 2010..

[8] Purwanto Yusdarmanto. Deep Mind Power Engineering. Jakarta: Prestasi. pages 36-412010. 